\title{
IMPLEMENTATION OF EU MERGER DIRECTIVE INTO THE SLOVAK LEGISLATION AND CERTAIN SELECTED TYPES OF RESTRUCTURING OF BUSINESS IN THE SLOVAK REPUBLIC
}

IMPLEMENTÁCIA EURÓPSKEJ SMERNICE O ZLÚČENÍ PODNIKOV DO SLOVENSKEJ LEGISLATÍVY A NIEKTORÉ VYBRANÉ TYPY REŠTRUKTURALIZÁCIE PODNIKOV V PODMIENKACH SR

\author{
Renáta KRAJČÍROVÁ* - Alexandra FERENCZI VAŇOVÁ **
}

\section{Introduction}

Restructuring a corporate entity is often a necessity when the company has grown to the point that the original structure can no longer efficiently manage the outputs and general interests of the company. In this respect, the article analyzes certain selected types of restructuring of businesses from the selected Slovak legal implications, such as (i) sale of business or the part of business, (ii) contribution in kind of business or the part of business, (iii) merger transaction.

The merger transactions are regulated by The Council Directive Council Directive 2009/133/EC of 19 October 2009 on the common system of taxation applicable to mergers, di-

\section{Abstract (EN)}

The article presents and explains transactions of restructuring of businesses in respect of taking over transactions from the Slovak and European tax point of view. The merger transactions from the tax perspective are regulated by The Council Directive 2009/133/EC of 19 October 2009 on the common system of taxation applicable to mergers, divisions, partial divisions, transfers of assets and exchanges of shares concerning companies of different Member States and to the transfer of the registered office of an SE or SCE between Member States. In this respect, the article analyzes certain selected types of restructuring of businesses, such as (i) sale of business or the part of business, (ii) contribution in kind of business or the part of business, (iii) merger transaction from the selected Slovak legal implications that can be used in the agribusiness sector.

\section{Keywords (EN)}

sale of business/or a part of business, contribution in kind of business or the part of business, merger transactions. visions, partial divisions, transfers of assets and exchanges of shares concerning companies of different Member $S$ and to the transfer of the registered office of an SE or SCE between Member States (further referred as" Merger Directive")

The main rule of the EU Merger Directive is that a merger, division, or partial division shall not give rise to any taxation of capital gains calculated by reference to the difference between the real values of the assets and liabilities transferred and their values for tax purposes.

The EU Merger Directive is transposed into the Slovak Income Tax Act ("Slovak ITA").The Slovak ITA essentially deals with business combinations, i.e. transactions involving mergers, de-mergers, contributions in kind as well as the sale of business or a part of business transactions.

\section{Abstrakt (SK)}

Príspevok prezentuje a objasňuje problematiku reštrukturalizačných transakcií podnikov s dôrazom na niektoré transakcie zlúčenia z pohladu slovenskej a európskej daňovej legislatívy. Z daňového pohladu transakcie zlúčenia upravuje Smernica Rady 2009/133/ES z 19. októbra 2009 o spoločnom systéme zdaňovania uplatnitelnom pri zlučovaní, rozdel'ovaní, čiastočnom rozdelovaní, prevode aktív a výmene akcií spoločností rôznych členských štátov a pri priemestnení sídla SE alebo SCE medzi členskými štátmi. V tejto súvislosti sa príspevok zaoberá niektorými vybranými spôsobmi reštrukturalizácie podnikov agrosektoru, ako napr. (i) predajom podniku alebo jeho časti, (ii) vkladom podniku alebo jeho časti, (iii) samotným zlúčením z pohladu vybraných dôsledkov slovenského práva.

\section{Klưčové slová (SK)}

predaj podniku/ alebo jeho časti, vklad podniku alebo jeho časti, zlúčenie podnikov 


\section{Restructuring of businesses}

Restructuring is the corporate management term for the act of reorganizing the legal, ownership, operational, or other structures of a company for the purpose of making it more profitable, or better organized for its present needs ${ }^{(1)}$.

Restructuring a corporate entity is often a necessity when the company has grown to the point that the original structure can no longer efficiently manage the outputs and general interests of the company. For example, a corporate restructuring may call for spinning off some departments into subsidiaries as a means of creating a more effective management model as well as taking advantage of tax breaks that would allow the corporation to divert more revenue to the production process. In this respect, the restructuring of business is seen as a positive sign of growth of the company and is often welcome by those who wish to see the corporation gain a larger market share.

As regards the restructuring of businesses including also the companies within the agribusiness operated in the Slovak Republic, the following options may be considered:

(i) Sale of business or the part of business,

(ii) Contribution in kind of business or the part of business, (iii) Merger transaction.

According to the Slovak legislation prior to the restructuring the businesses to be transferred should represent independent organisational unit of the Slovak company. The assets and liabilities relating to that part of business should be separable from the books of the company.

It should be noted that the Slovak law contains "the substance over form" provision. Based on this rule, it is necessary to take into account the actual substance of a particular transaction and to disregard formal structuring of the transaction. When applying the tax laws, the actual content of a legal transaction and other facts decisive for determination or collection of the tax should be taken into account.

\section{EU Merger Directive}

The Council Directive Council Directive 2009/133/EC of 19 October 2009 on the common system of taxation applicable to mergers, divisions, partial divisions, transfers of assets and exchanges of shares concerning companies of different Member State and to the transfer of the registered office of an SE or SCE between Member States (further referred as" Merger Directive") is transposed into the Slovak Income Tax Act (further "ITA" or "Slovak ITA"). In general, the Merger Directive $^{(2)}$ is applicable to mergers, divisions, partial divisions, transfers of assets and exchange of shares involving companies from two or more member states.

For the purposes of the EU Merger Directive merger trans-

(1) Wikipedia, the free encyclopedia

(2) Council Directive Council Directive 2009/133/EC of 19 October 2009 on the common system of taxation applicable to mergers, divisions, partial divisions, transfers of assets and exchanges of shares concerning companies of different Member State and to the transfer of the registered office of an SE or SCE between Member States (codified version) action means an operation, when:

(i) one or more companies, on being dissolved without going into liquidation, transfer all their assets and liabilities to another existing company in exchange for the issue to their shareholders of securities representing the capital of that other company, and, if applicable, a cash payment not exceeding $10 \%$ of the nominal value, or, in the absence of a nominal value, of the accounting par value of those securities;

(ii) two or more companies, on being dissolved without going into liquidation, transfer all their assets and liabilities to a company that they form, in exchange for the issue to their shareholders of securities representing the capital of that new company, and, if applicable, a cash payment not exceeding $10 \%$ of the nominal value, or in the absence of a nominal value, of the accounting par value of those securities;

(iii) a company, on being dissolved without going into liquidation, transfers all its assets and liabilities to the company holding all the securities representing its capital.

The main rule of the Merger Directive is that a merger, division, or partial division shall not give rise to any taxation of capital gains calculated by reference to the difference between the real values of the assets and liabilities transferred and their values for tax purposes.

The amendment to the Slovak ITA effective as of 1 January 2010 essentially deals with business transformation, i.e. transactions involving mergers, de-mergers, contributions in kind as well as the sale of business or a part of business transactions.

\section{Selected types of restructuring of busi- nesses}

\section{Sale of business or the part of business (Sale)}

\section{Short legal introduction}

According to the Slovak Commercial Code upon a contract on the sale of business/a part of business the seller is obliged to transfer to the buyer all assets, rights and other property related to the operation of the business and the buyer is obliged to assume all obligations related to the operation of the business and to pay the purchase price.

With the business or its parts all rights and obligations related to the operation of the business shall pass to the buyer, whereby the provisions related to receivables assignment should apply. The transfer of rights and obligations does not include so called "public" liabilities, e.g. tax liabilities, which remain with the seller.

A sale of business or its part must also be registered with the Commercial Register; effectiveness of the contract is not conditioned with such registration.

The transfer of assets from the seller to the buyer must also include the employment relations. Therefore, all liabilities associated with employment relations should be transferred to the buyer (liabilities against employees to pay out the salaries for the work performed on behalf of the seller in the month 
preceding the sale), i.e. they should be included in the transferred part of business. The reserves for bonuses, premiums, employment benefits or untaken holidays should be treated accordingly.

Further, according to Article 59a of the Slovak Commercial Code should the company be acquiring assets, based on the contract with its shareholder of incorporator or party related to any of them, for value of more than $10 \%$ of the registered capital of the company, the value of the assets must be determined by a sworn valuer (expert).

\section{Accounting implications}

The sale of the part of business should be booked as of the effective date of the sale contract.

According to the Slovak accounting legislation in case of the sale of business / a part of business, the seller shall account for the sold assets by means of a debit entry in account 588 - Other extraordinary expenses and for liabilities a credit entry in account 688 - Other extraordinary income; the selling price of the business / a part of business shall be debited to account 371 - Receivables related to the sale of business with the corresponding entry on the credit side of account 688. The difference between accounts 588 and 688 would represent the profit or loss from the sale of business / part of business in the accounting books of seller.

In general, according to the Slovak accounting legislation the buyer shall account for the particular purchased asset items of the business/part of business on the respective asset accounts and the assumed liabilities shall be credited to the respective liabilities accounts. The purchase price shall be credited to account 372 - Liabilities related to purchase of business.

It is necessary to point out that no obligation to prepare extraordinary financial statements as of the date of the sale of business/ a part of business would arise for seller.

\section{Selected corporate income tax consequences}

While the tax treatment of mergers, de-mergers, contributions in-kind allows the tax payers to choose from two regimes of valuation of assets transferred in the course of the above transactions (based on the fair value of assets or based on the original tax value of assets), the amendment of ITA specifies only one possible treatment for the sale of business/ part of business transactions.

Asset and liability items transferred upon a sale of business/a part of business should always be valued for tax purposes at their fair values according to accounting regulations. This means that the buyer should value the asset and liability items acquired upon the purchase of business or its part for tax purposes at their fair values.

According to the Slovak ITA, the goodwill or negative goodwill arising at the buyer of a business/a part of business should be included into its tax base over a maximum of seven taxation periods starting with the period in which it arose (i.e. in the year of the purchase of business) in the amount of at least one seventh of the value of the goodwill/ negative goodwill.

Any capital gain from the sale of the business/part of business should be included in the tax base of the seller in the tax- ation period in which the contract on the sale of business/a part of business becomes effective. The capital gain will be subject to current corporate income tax at a rate of $22 \%$.

The ITA (Article 17a) stipulates several specific adjustments of the tax base resulting from the sale of business/a part of business at the seller in the taxation period in which the agreement of the sale of business/part of business becomes effective.

\section{Contribution of business or the part of business (Contribution)}

Legal introduction

Under the provisions of the Slovak Commercial Code the contribution in kind may only consist of assets whose economic value may be appraised in monetary terms. Therefore, an expert valuation of the assets to be contributed must be prepared. Apart from other essential information, the valuation must also contain information on the amount up to which the value of the asset shall be considered as a contribution into the registered capital.

A contribution in kind could comprise either individual assets (or set of assets); or business/part of a business. Should the business or its part is contributed the provisions on the sale of business or its part of the Slovak Commercial Code are used. Following the above, with the business or its parts all rights and obligations related to the operation of the business shall be taken over by recipient. The contribution in kind of the business or its part includes also the employment relations.

\section{Accounting implications}

The Slovak accounting regulations requires to record profit/ loss on contribution (investment revaluation reserve) upon the in-kind contribution at the contributor's books. The financial investment is recorded by contributor in the amount of acknowledged value of the in-kind contribution recognised as the value of the contribution.

According to the Article 27a of the Slovak accounting standards the difference between the acknowledged value of the contribution (investment) and the net book value of contributed part of business thereof (investment revaluation reserve) is recorded in the accounting books of the contributor based on its character (i) either to the debit side of the account 568 - Other financial expenses or (ii) to the credit side of the account 668 - Other financial revenues

Upon the in-kind contribution of business or a part of business the acquired asset and liability items are booked in the respective accounts to which they belong in substance at their fair value based on Article 27(2) of the Act on Accounting.

The difference between the fair value of respective assets and liabilities and the acknowledged value of the in-kind contribution recognised as the value of the contribution by the shareholder is considered a goodwill or a negative goodwill. The goodwill or a negative goodwill should be recorded in the account 015 - Goodwill. This goodwill or negative goodwill will be depreciated for the accounting purposes depending on the period of its use (the possibility of the good- 
will to influence of the future increase/decrease of economic benefits for the accounting unit.

\section{Selected corporate income tax consequences}

Following the Slovak implementation of Merger Directive, the contribution of business or its part is generally treated as not giving rise to a taxable capital gain unless the recipient of assets and liabilities subject to transfer upon the contribution of business or its part may benefit from fair value of contributed assets for tax purposes.

In this respect, according to the ITA for tax purposes, it could be chosen whether the fair values of the assets and liabilities or their historic values are taken over by recipient upon the contribution for tax purposes. In case of taking over the fair values for tax purposes, the valuation differences recorded by contributor in its revenues shall be part of the tax base. It could be further chosen whether these differences are included into the tax base in the first taxation period or in parts (during maximum of 7 tax periods and at least in the amount of $1 / 7$ of the evaluation differences per tax period). In case of taking over the historic values for tax purposes, the valuation differences recorded in contributor's revenues are not included in its tax base.

The recipient from a tax perspective would have the following major tax implications depending on the option of historic vs. fair values of assets are used. In case of taking over the fair values for tax purposes, fair values of contributed assets and liabilities will be used for tax purposes. The goodwill in this case shall be included into the tax base for a maximum of seven taxation periods, but at least in $1 / 7$ of the reported goodwill on an annual basis. In case of taking over the historic values for tax purposes, according to the ITA, the recipient will not include goodwill into its tax base.

In addition, the ITA determines also quite detailed procedures of including of provisions and adjustments to the tax bases of contributor and recipient depending on the opted alternative of taking over the historic values or fair values of the assets and liabilities.

\section{Merger transaction}

\section{Legal introduction}

According to the Slovak Commercial Code merging and successor companies must have the same legal form. From the legal perspective, this means that only the companies with the same legal form should be subject to merger transaction.

In general, on merger by acquisition one or more companies will cease to exist ("the company or companies being acquired" or "the merging company") this being preceded by its (their) winding-up without liquidation; the business assets of the merging company including its rights and obligations (duties) arising from labour relations, shall pass to another company ("the acquiring company" or "the successor company"). Members (shareholders) of the merging company shall become members (shareholders) of the acquiring (i.e. successor) company.

It is likely that the "transformation" or "take over" of company (or the branch) into the new entity would be treated as contribution in kind of business or a part of business to the successor company (or new established entity).

\section{Accounting implications}

According to the Slovak accounting procedures, in the course of the merger transaction, the assets and liabilities of merging company should be revaluated to the fair value. Therefore, the revaluation difference is to be declared in the books of merging company. Further, the revaluated fair values shall be taken over to the accounting records of successor company.

The difference between the book value of merging company (acquisition price) in the books of successor company and the fair value of the assets and liabilities of merging company represents goodwill/badwill. This difference should be recorded in the books of successor company.

The goodwill/badwill is to be adjusted by certain items, by its expected economical benefits, and depreciated for accounting purposes.

\section{Selected corporate income tax consequences}

In general, following the implementation of "Merger Directive", the merger transaction is generally treated as not giving rise to a capital gain. As a result, according to the Slovak ITA, the income received from acquiring new shares and income from exchange of the shares on merger is not subject to tax.

From the Slovak tax perspective, it could be chosen whether the fair values of the assets and liabilities or their historic values are taken over in respect of the merger transaction. In case of taking over the fair values for tax purposes, the revaluation differences should be a part of the tax base. It could be further decided whether these differences are to be included into the tax base of merging or successor company and included into the tax base (in one taxation period or in parts during maximum seven taxation periods). In case of taking over the historic values for tax purposes, the revaluation differences are not to be included in the tax base of successor company.

It should be further noted that the Slovak ITA determines also quite detailed procedures of including of provisions and adjustments to the tax bases of both companies depending on the opted alternative of taking over the historic values or fair values of the assets and liabilities.

\section{Value Added Tax consequences}

Under general VAT principles, the transfer of a business should be VAT neutral (out of scope of VAT) on basis that the entity acquiring the business continues to operate the business (so called transfer of going concern).

From the Slovak Value Added Tax perspective, the sale of business or its part representing a separate organisational unit of the VAT payer or the contribution of a business or its part into a commercial company or a cooperative is outside the scope of VAT provided that the buyer is registered (or becomes registered) for VAT purposes upon the sale or contribution, except for cases where the acquirer solely or prevailingly supplies goods and services exempt from the VAT (without the right for input VAT deduction e.g. in case of financial institutions). The acquirer becomes a VAT payer automatically on the day it acquires a business or its part in 
both cases, i.e. in case of the sale of business or the contribution of the business.

\section{Conclusion}

Restructuring a corporate entity is often a necessity when the company has grown to the point that the original structure can no longer efficiently manage the outputs and general interests of the company. In this respect, the restructuring of business is seen as a positive sign of growth of the company.

The Council Directive Council Directive 2009/133/EC of 19 October 2009 on the common system of taxation applicable to mergers, divisions, partial divisions, transfers of assets and exchanges of shares concerning companies of different Member S and to the transfer of the registered office of an SE or SCE between Member States is transposed into the Slovak Income Tax Act. In general, the Merger Directive is applicable to mergers, divisions, partial divisions, transfers of assets and exchange of shares involving companies from two or more member states.

As regards the restructuring of businesses operated within the agribusiness sector in the Slovak Republic, the paper analyzes certain selected options (i) Sale of business or the part of business, (ii) Contribution in kind of business or the part of business, (iii) Merger transaction from the Slovak legal perspective.

\section{References}

1. Council Directive 2009/133/EC of 19 October 2009 on the common system of taxation applicable to mergers, divisions, partial divisions, transfers of assets and exchanges of shares concerning companies of different Member State and to the transfer of the registered office of an SE or SCE between Member States (codified version)

2. Zákon č. 513/1992 Zb. Obchodný zákonník v znení neskorších predpisov

3. Zákon č. 595/2003 Z. z. o dani z príjmov v znení neskorších predpisov

Contact address/ Kontaktná adresa

Ing. Renáta Krajčírová, PhD.

Department of Enterprise's Information Systems,

Faculty of Economics and Management, SUA in Nitra,

Tr. A. Hlinku 2, 94976 Nitra,

Email: renata.krajcirova@uniag.sk

Ing. Alexandra Ferenczi Vaňová, PhD.

Department of Enterprise's Information Systems,

Faculty of Economics and Management, SUA in Nitra,

Tr. A. Hlinku 2, 94976 Nitra,

Email: alexandra.ferenczi@uniag.sk 